\title{
Bacterial overgrowth can be detected by breath hydrogen measurement before clinical manifestations in suckling lambs
}

\author{
András Jávor ${ }^{1 *}$, Anikó Nagy ${ }^{1,2^{*}}$, Ágnes Papp-Bata ${ }^{3}$, Nóra Vass ${ }^{1}$, János Oláh ${ }^{1}$, Zoltán Csiki \\ University of Debrecen, ${ }^{1}$ Faculty of Agricultural and Food Sciences and Environmental Management, \\ Department of Animal Breeding, ${ }^{2}$ Faculty of Medicine, Division of Clinical Immunology, \\ ${ }^{3}$ Faculty of Applied Economics and Rural Development, Debrecen, Hungary \\ *The first two authors contributed equally to this work
}

Received October 6, 2014

Accepted February 25, 2015

\begin{abstract}
Hydrogen breath test is a non-invasive and inexpensive method for estimation of small bowel transit time, detection of excess bacteria in the small intestine and demonstration of maldigestion or malabsorption. Until now, little has been known about breath hydrogen excretion in lambs. The aim of our study was to assess the patterns of breath hydrogen excretion in lambs before and after feeding ewe's milk, and to evaluate pathological and/or physiological alterations in the lambs' gastrointestinal function. We assumed that intestinal disorders may influence the breath hydrogen concentrations, which could be detected early in the subclinical stage. A total of 52 healthy blackheaded Dorper lambs were included in the study. Breath hydrogen was measured after overnight fasting and at 30,60 and $90 \mathrm{~min}$ after the start of feeding. There was a 2-week follow-up period after the measurements to assess the gastrointestinal health of lambs. During the follow-up period, clinical signs of diarrhoea developed in 6 lambs. Based on our results in healthy lambs, the median concentration of baseline breath hydrogen was 1.00 parts per million (minimum: 0.00, maximum: 2.00). We observed a significant elevation in breath hydrogen concentrations $60 \mathrm{~min}$ after feeding $(P=0.004)$, whereas the values detected $30 \mathrm{~min}$ after feeding were similar to the baseline values. Regarding the lambs in which clinical signs of diarrhoea developed, we revealed significantly higher baseline breath hydrogen concentrations compared to those which remained healthy $(P<0.001)$. Our observations underline that hydrogen breath test may be a useful tool for indicating potential bacterial overgrowth before any clinical signs of diarrhoea.
\end{abstract}

Diagnosis, diarrhoea, hydrogen breath test

Hydrogen breath test is a simple, non-invasive and inexpensive method for estimating small bowel transit time, detecting the existence of excess bacteria in the small intestine, and demonstrating carbohydrate maldigestion or malabsorption (Washabau et al. 1986; Misselwitz et al. 2013). The rationale of hydrogen breath tests is based on the concept that parts of the gas produced by colonic bacteria fermentation diffuse into the blood and are rapidly excreted by breath (D'Angelo et al. 2013). One of the exhaled substances is hydrogen, which can be measured relatively easily with the help of handy breath test devices. Hydrogen in the exhaled air was only generated during anaerobic metabolism, consequently, the hydrogen measured in the exhaled breath sheds light on the quantity and metabolic activity of anaerobic bacteria in the gut (Mastropaolo and Rees 1987). Unabsorbed dietary carbohydrates that reach the colon are metabolized by bacteria to hydrogen, methane, and short chain fatty acids (Gasbarrini et al. 2009). Hydrogen measurement is routinely used in human medicine to investigate the gastrointestinal function. This method has been applied successfully to the clinical investigation of small intestinal carbohydrate malabsorption (Levitt and Donaldson 1970; Bond and Levitt 1976), small intestinal bacterial overgrowth (Metz et al. 1976) and for the assessment of mouth-to-caecum transit time (Bond et al. 1975). The development of portable breath

Address for correspondence:

Zoltán Csiki MD, PhD

Division of Clinical Immunology

Faculty of Medicine, University of Debrecen

Moricz Zs. str. 22

Phone: +36-52-255-218

H-4032 Debrecen, Hungary 
hydrogen monitors may permit cheaper and more practical breath hydrogen measurement to be used as an ancillary test in veterinary practice.

Until now, little has been known about the patterns of breath hydrogen excretion in suckling lambs. Importantly, postnatal growth in ruminant animals is divided into two physiologically distinct stages: the preruminant (milk-fed) phase and the postweaning ruminant phase. In the first phase, the digestive system is comparable to the ones in monogastric animals or humans, and later, weaning stimulates rumen development and microbial fermentation (Bellver et al. 1995; Álvarez-Rodríguez et al. 2012). As the hydrogen concentration measured in the exhaled air is always a reflection of the mass of bacteria and of the bacterial metabolic activity in the intestines, hydrogen breath test can be a useful method for screening and investigating the suckling lambs' intestinal health and fermentation. The intestinal health of lambs is a very serious issue and a "weak link" in their nursing. The aim of the present study was to evaluate the changes of breath hydrogen concentrations over time, and to assess the associations between measured values and gastrointestinal symptoms of the lambs included in the research.

\section{Animals \\ Materials and Methods}

A total of 52 black-headed Dorper lambs were included in the study. The age of the studied group was 15.4 \pm 1.6 days, and their weight was $6.59 \pm 1.74 \mathrm{~kg}$. All animals were considered healthy according to veterinary clinical examination. All animals had no evidence of a systemic disease and received no antibiotics in 2 weeks prior to the study. The animals and their dams were kept on an experimental farm. The lambs were fed ewe's milk only. The dams were fed separately from their lambs, thus the lambs had no access to solid feed.

\section{Breath collection and sampling}

Breath samples were collected by using a portable breath hydrogen monitor device (Gastro ${ }^{+}$Gastrolyser, Bedfont Scientific Ltd., Rochester, Kent, ME1 3QX, England). The collection system was composed of a FlatPak mouthpiece, a D-piece, a facemask, and a Y-piece. Appropriate facemask was used according to the lamb's face and mouth size. The facemask was fitted to the lamb's mouth, and the lamb was allowed to breathe normally through the mask for $30 \mathrm{~s}$. The instrument measures hydrogen concentration in parts per million (ppm) within the concentration range of $0-500 \mathrm{ppm}$. Before use, the hydrogen monitor was calibrated with Bedfont $100 \mathrm{ppm}$ hydrogen in air gas.

Before the day of measurements, the lambs were weaned from their dams overnight for a 12-14 h fasting. The first measurement was performed before the dams were allowed to breast-feed their lambs. The feeding took $30 \mathrm{~min}$, thereafter the lambs were separated again from their dams, and we carried out the second measurement which was followed by two further measurements at 30 min intervals.

There was a two-week follow-up after the measurements in order to assess the gastrointestinal health of the lambs. General clinical examinations and investigations of clinical sings of diarrhoea were performed in all lambs daily.

\section{Statistical analysis}

The SPSS ver. 20.0 (SPSS Inc., Chicago, IL, UDA) was used for statistical analysis. To assess the distribution of the data Kolmogorov-Smirnov test was used. In cases of normal distribution, we determined the mean \pm standard deviation (SD) values and used two-sample $t$-test for statistical comparison of the experimental data. In cases of distributions different than normal, median, minimum, and maximum values were calculated, and MannWhitney and Wilcoxon tests were used. Differences were considered significant at $P<0.05$.

\section{Results}

During the follow-up period, clinical signs of diarrhoea developed in six lambs. Therefore we divided the lambs into two groups before the statistical evaluation. Group A consisted of 46 lambs without any signs of diarrhoea. The median concentration of baseline breath hydrogen of healthy lambs (group A) was $1.00 \mathrm{ppm}$ (minimum: $0.00 \mathrm{ppm}$, maximum: $2.00 \mathrm{ppm})$. We compared baseline values with the results measured $30 \mathrm{~min}$ [median: $1(0.00-6.00) \mathrm{ppm}$ ], $60 \mathrm{~min}$ [median: $1(0.00-7.00) \mathrm{ppm}$ ] and $90 \mathrm{~min}$ after the start of 
feeding [median: $4(0.00-7.00) \mathrm{ppm}$ ]. Based on our observations, the elevation in breath hydrogen concentrations became significant at 60 min after feeding $(P=0.004)$ (Fig. 1).

Six lambs showing clinical signs of diarrhoea formed group B. In this group we compared baseline values [median: $7.5(7.00-8.00) \mathrm{ppm}$ ] with the results measured $30 \mathrm{~min}$ [median: 7.5 (7.00-8.00) ppm], 60 min [median: $8(7.00-9.00) \mathrm{ppm}$ ] and $90 \mathrm{~min}$ after the start of feeding [median: 9 (7.00-10.00) ppm]. Based on our observations, the elevation in breath hydrogen concentrations became significant at 90 min after feeding in group B $(P=0.046)$ (Fig. 1).

Interestingly, when we compared the results measured in the two animal groups, we found that lambs in group B had significantly higher baseline concentrations of breath hydrogen compared to the lambs without any signs of diarrhoea $(P<0.001)$. That significant difference between group $\mathrm{A}$ and $\mathrm{B}$ remained stable at each time point after feeding, as well $(P<0.001)$ (Fig. 1).

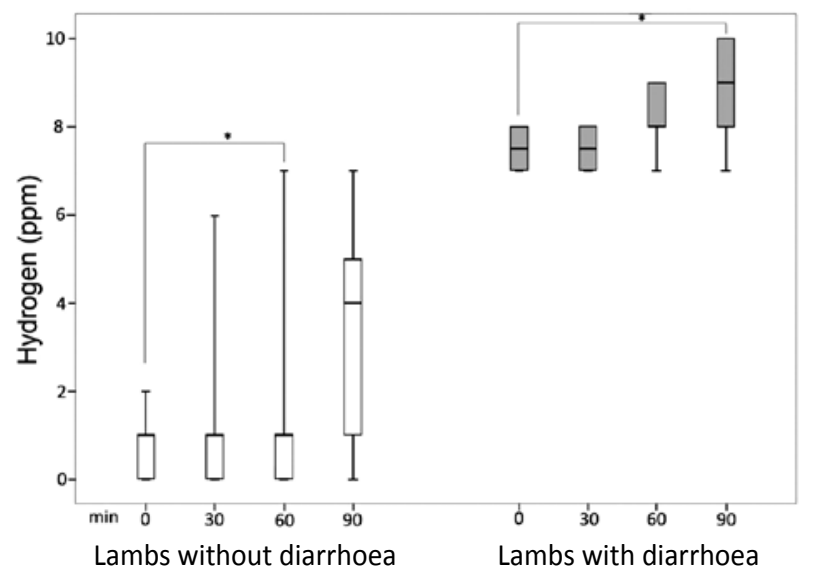

Fig. 1. Effects of feeding on breath hydrogen concentrations in healthy lambs.

Box plots show median, upper and lower quartiles, lines extending vertically from boxes indicate minimum and maximum values. The development of significant differences $(P<0.05)$ within each group is indicated by $(*)$. Differences between the two lamb groups were significant at each time point.

\section{Discussion}

The collection technique with facemasks used in the present study had already been applied to clinical investigation of gastrointestinal disorders in calves (Holland et al. 1986; 1989), dogs (Washabau et al. 1986), and cats (Muir et al. 1991). Nappert et al. (1993) investigated the breath hydrogen excretion with facemask in 12 healthy and 18 diarrhoeic calves and reported a significant increase in $\mathrm{H}^{2}$ excretion in diarrhoeic versus control animals.

Since there is no former study in international scientific literature about the assessment of exhaled breath hydrogen in lambs, the primary aim of our study was to determine the breath hydrogen values of the healthy lambs, and evaluate their changes after feeding the animals. The basic value of breath hydrogen was around $1.00 \mathrm{ppm}$, which is similar to the baseline values formerly measured in calves (Nappert et al. 1993). Based on our results, breath hydrogen concentrations increase significantly 60 min after the start of feeding, due to the metabolic activity of the gastrointestinal microbiome. Of note, in the present study we investigated suckling lambs only, in which the function of the digestive system 
is comparable to that of monogastric animals or humans. Our measurements were carried out before the introduction of solid food and rumen development of the young ruminants.

During the follow-up period, clinical signs of diarrhoea developed in 6 lambs. The statistical evaluation revealed significantly higher baseline breath hydrogen concentrations in these lambs, compared to those which remained healthy in the investigated period. Of note, that significant difference between breath hydrogen concentrations of groups A and B remained stable at each time point after feeding. The high breath hydrogen concentration may indicate an intestinal bacterial overgrowth. Detection of microbial imbalances in the gut is an important issue, because this condition may potentially lead to loss of appetite, diarrhoea, and even delayed growth in the affected lambs (Kiss 2002); moreover, lambs suffering from diarrhoea cannot be transported and sold (Tildi 1982; Jávor et al. 2002). Consequently, diarrhoea is an important welfare and economic issue for sheep enterprises worldwide (Jacobson et al. 2009). The aetiology of the diarrhoeal syndrome is quite complex involving many infectious agents of bacterial, viral, and protozoan nature (Wani et al. 2004). A large number of infectious and non-infectious agents have been associated with diarrhoea in naive lambs, including strongylid nematodes (Sargison 2004). Prediction of diarrhoeic lambs would be very important before the occurrence of symptoms. Of note, small intestinal bacterial overgrowth (SIBO) can be diagnosed directly with quantitative bacterial culture (Rutgers et al. 1995) or indirectly by detecting subnormal serum cobalamin and supranormal folate concentrations (Suchodolski and Steiner 2003; Dossin 2011). These tests are commonly used in canine and feline practice, but not in small ruminants. Moreover, these methods are expensive and/or invasive and not suitable for routine screening.

We have described a successful non-invasive and inexpensive method for breath hydrogen measurement in suckling lambs and assessed the breath hydrogen values of healthy and fasted lambs. Based on our observations, we assume that intestinal disorders influence the value of breath hydrogen, and these changes can be detected early in the subclinical stage. Consequently, breath hydrogen measurement of lambs could be a supplemental diagnostic tool in small ruminant veterinary medicine.

\section{References}

Álvarez-Rodríguez J, Monleón E, Sanz A, Badiola JJ, Joy M 2012: Rumen fermentation and histology in light lambs as affected by forage supply and lactation length. Res Vet Sci 92: 247-253

Bellver SP, Beermann DH, Bell AW, Van Tassell CP, Hogue DE, McLaughlin CL 1995: Effects of exogenous somatotropin on whole-body glycemic response to insulin in young preruminant and ruminant lambs. Domest Anim Endocrinol 12: 143-156

Bond JH, Levitt MD 1976: Quantitative measurement of lactose absorption. Gastroenterology 70: $1058-1162$

Bond JH, Levitt MD, Prentiss R 1975: Investigation of small bowel transit in man utilizing pulmonary hydrogen (Hz) measurements. J Lab Clin Med 85: 546-555

D’Angelo G, Di Rienzo TA, Scaldaferri F, Del Zompo F, Pizzoferrato M, Lopetuso LR, Laterza L, Bruno G, Petito V, Campanale MC, Cesario V, Franceschi F, Cammarota G, Gaetani E, Gasbarrini A, Ojetti V 2013: Tricks for interpreting and making a good report on hydrogen and $13 \mathrm{C}$ breath tests. Eur Rev Med Pharmacol Sci 17: Suppl 2, 90-8

Dossin O 2011: Laboratory tests for diagnosis of gastrointestinal and pancreatic diseases. Top Companion Anim Med 26: 86-97

Gasbarrini A, Corazza GR, Gasbarrini G, Montalto M, Di Stefano M, Basilisco G, Parodim A, Usai-Satta P, Vernia P, Anania C, Astegiano M, Barbara G, Benini L, Bonazzi P, Capurso G, Certo M, ColecchiaA Cuoco L, Di Sario A, Festi D, Lauritano C, Miceli E, Nardone G, Perri F, Portincasa P, Risicato R, Sorge M, Tursi A 2009: Methodology and indications of H2-breath testing in gastrointestinal diseases: the Rome Consensus Conference. Aliment Pharmacol Ther 29: S1:1-49

Holland RE, Herdt TH, Refsal KR 1986: Breath hydrogen concentration and small intestinal malabsorption in calves. Am J Vet Res 41: 2020-2024

Holland RE, Herdt TH, Refsal KR, 1989: Pulmonary excretion of H2 in calves with cryptosporidium-induced malabsorption. Dig Dis Sci 34: 1399-1404 
Jacobson C, Bell K, Besier RB 2009: Nematode parasites and faecal soiling of sheep in lairage: Evidence of widespread potencial production losses for the sheep industry. Animal Production Sci 49: 326-332

Jávor A, Kukovics S, Molnár Gy, Nábrádi A, Szücs I 2002: The earnings of the sector [in Hungarian] In: Nábrádi A, Jávor A (Eds): Economical organization of sheep breeding [in Hungarian]. Szaktudás Kiadó Ház, Budapest, pp. 113-117. ISBN 9639422037

Kiss Zs 2002: Infectious diseases [in Hungarian] In: Duduk V, Egri B, Kiss Zs, Pinnyei Sz, Várnagy L (Eds): Protection of animal health [in Hungarian]. Mezőgazdasági Kiadó, Budapest, pp. 154-245. ISBN 9639358495

Levitt MD, Donaldson RM 1970: Use of respiratory hydrogen excretion to detect carbohydrate malabsorption. J Lab Clin Med 75: 937-945

Mastropaolo G, Rees WD 1987: Evaluation of the hydrogen breath test in man: definition and elimination of the early hydrogen peak. Gut 28: 721-725

Metz G, Gassul MA, Drasar BS, Jewnkins DJA, Blendins LM 1976: Breath hydrogen test for small intestinal bacterial colonisation. Lancer 1: 668-669

Misselwitz B, Pohl D, Frühauf H, Fried M, Vavricka SR, Fox M 2013: Lactose malabsorption and intolerance: pathogenesis, diagnosis and treatment. United European Gastroenterol J 3: 151-159

Muir P, Papasoutiotis K, Gruffydd-Jones TJ, Cripps PJ, Harbour DA 1991: Evaluation of carbohydrate malassimilation and intestinal transit time in cats by measurement of breath hydrogen excretion. Am J Vet Res 52: 1104-1109

Nappert G, Hamilton D, Petrie L, Naylor JM 1993: Determination of lactose and xylose malabsorption in preruminant diarrheic calves. Can J Vet Res 57: 152-158

Rutgers HC, Batt RM, Elwood CM, Lamport A 1995: Small intestinal bacterial overgrowth in dogs with chronic intestinal disease. J Am Vet Med Assoc 206: 187-193

Sargison ND 2004: Differential diagnosis of diarrhea in lambs. In Practice 26: 20-27

Suchodolski JS, Steiner JM 2003: Laboratory assessment of gastrointestinal function. Clin Tech in Small Anim Pract 18: 203-210

Tildi I 1982: Holding company, industrial engineering [in Hungarian] In: Averjanov A (Ed.): Guide for sheep breeding [in Hungarian]. Mezőgazdasági Kiadó, Budapest, pp. 437-474

Wani SA, Bhat MA, Samanta I, Ishaq SM, Asharfi MA, Buchh AS 2004: Epidemiology of diarrhoea caused by rotavirus and Escherichia coli in lambs in Kashmir valley, India. Small Rum Res 52: 145-153

Washabau RJ, Strombeck DR, Buffington CA, Harrold D 1986: Use of pulmonary hydrogen gas excretion to detect carbohydrate malabsorption in dogs. J Am Vet Med Assoc 189: 674-679 